\title{
Can Crude Oil Futures Predict Spot Retail Unleaded Gasoline Prices?
}

Vance Ginn

Texas Tech University • Lubbock, TX

Ronald D. Gilbert

Texas Tech University • Lubbock, TX

\begin{abstract}
The motivation for this paper began with casual empiricism regarding the brief distributed lag of retail gasoline prices behind crude oil futures. We developed a model consistent with our hypothesis and tested it with econometrics using statistical data that include the sharp decrease in crude oil price futures in late summer 2008. We found that our model is a consistent and efficient estimator of the actual gasoline prices over most of our sample period. However, random shocks to gasoline prices, like Hurricane Ike in 2008 , cause the model to have problems accurately predicting gas prices. We conclude that our estimated model and simulations provide reasonable support for our hypothesis that crude oil price futures can predict spot retail unleaded gasoline prices.
\end{abstract}

\section{Introduction and Background}

The motivation for this paper began with separate instances of casual empiricism by the two authors in the community where we live and work. One author made a habit of noting near-term futures prices of unleaded gasoline on the New York Mercantile Exchange (NYMEX), adding sixty cents to those prices, and being able to predict what discount retailers would charge for regular unleaded gasoline that week in our local markets.

The other co-author spent one and one-half years tracking crude oil futures prices on the NYMEX and their correlations with retail gasoline prices at a brand name outlet in our local market. This led to the creation of a formal model to forecast future changes in spot retail unleaded gasoline prices at the local outlet. This model can be expressed as follows:

$$
E\left(G_{t+1}\right)-G_{t}=\left[G_{t} / O_{t}\right]\left(O_{t}-O_{t-1}\right)
$$

A numerical example illustrates this model. Assume that the retail unleaded gasoline price $\left(G_{1}\right)$ is $\$ 3.00$, and the change in the futures price of crude oil 
$\left(\mathrm{O}_{t}-\mathrm{O}_{\mathrm{t}-1}\right)$ is a $\$ 1.00$ increase to $\$ 80$ in time period $(\mathrm{t})$. The model predicts that spot unleaded gasoline will increase from $\$ 3.00$ to $\$ 3.0375$ in time period $(t+1)$ which is one day later than $(t)$.

While these casual empiricisms gave us a good indicator of where our research and model were headed, we decided it was necessary to expand our ideas and formulate a linear model from our additional findings. The first of these findings was the four major components of the price of a gallon of gasoline. These components are distribution and marketing, refining costs and profits, federal and state taxes, and crude oil (see Figure 1). We look at each of these four components as a percentage of the average retail price of a gallon of unleaded gasoline. As Figure 1 shows, the average retail price of a gallon of regular unleaded gasoline has increased 136\% from January of 2000 to August of 2008. From the findings in Chouinard and Perloff (2002), we note that there is a consistent rise in the percentage that is related to crude oil prices relative to the price of gas. As the price of oil moved close to $\$ 145$ a barrel in 2008 , the crude oil price contributed $73 \%$ to the price of a gallon of gas compared to $46 \%$ in 2000 and $58 \%$ in 2007 . This signals that there is a direct and persistent relationship between higher crude oil prices and higher retail gasoline prices.

Although refining costs have also increased during the last few years due to an increase in the cost of raw materials, as a percentage, these costs have been reduced over time. Over the last several years the tax rates on gasoline at the state and federal government levels have remained relatively unchanged, but the percentage of the cost from these taxes on retail gasoline prices has fallen as crude oil prices have risen. Distribution and marketing costs in dollar terms have risen due to the higher price of gasoline and increased expenditures by oil companies on ad campaigns in defense of an industry that was criticized as retail prices of their products increased. However, these costs over time have also decreased as a percentage of retail gasoline prices.

Collectively, we have evaluated this information and concluded that the price of crude oil is the most significant variable affecting the national retail gasoline price. Given this fact, we needed to find the best way to show this. One may look at either the spot price or the NYMEX futures price of oil. From our findings and from our literature review, we conclude that the futures price of crude oil is the best measure to use to predict future spot retail unleaded gasoline prices. This makes sense since the retailers will have to make pricing decisions at the margin when it comes to their overall costs. Since crude oil, as a percentage, is the number one component in a gallon of gas, future costs of crude oil will allow rational store owners to expect that their costs will change and consequently decide to change their price 
of gasoline. These changes in gas prices sum together on a national scale to make up the national average price of gasoline. While there are many implications of being able to correctly predict future energy prices, such as gasoline, we would only like to evaluate our findings from the model and provide forecasts to determine whether the model does a good job at modeling the behavior of the actual national average of retail gasoline prices.

Figure 1

Average Yearly Retail Gas Components

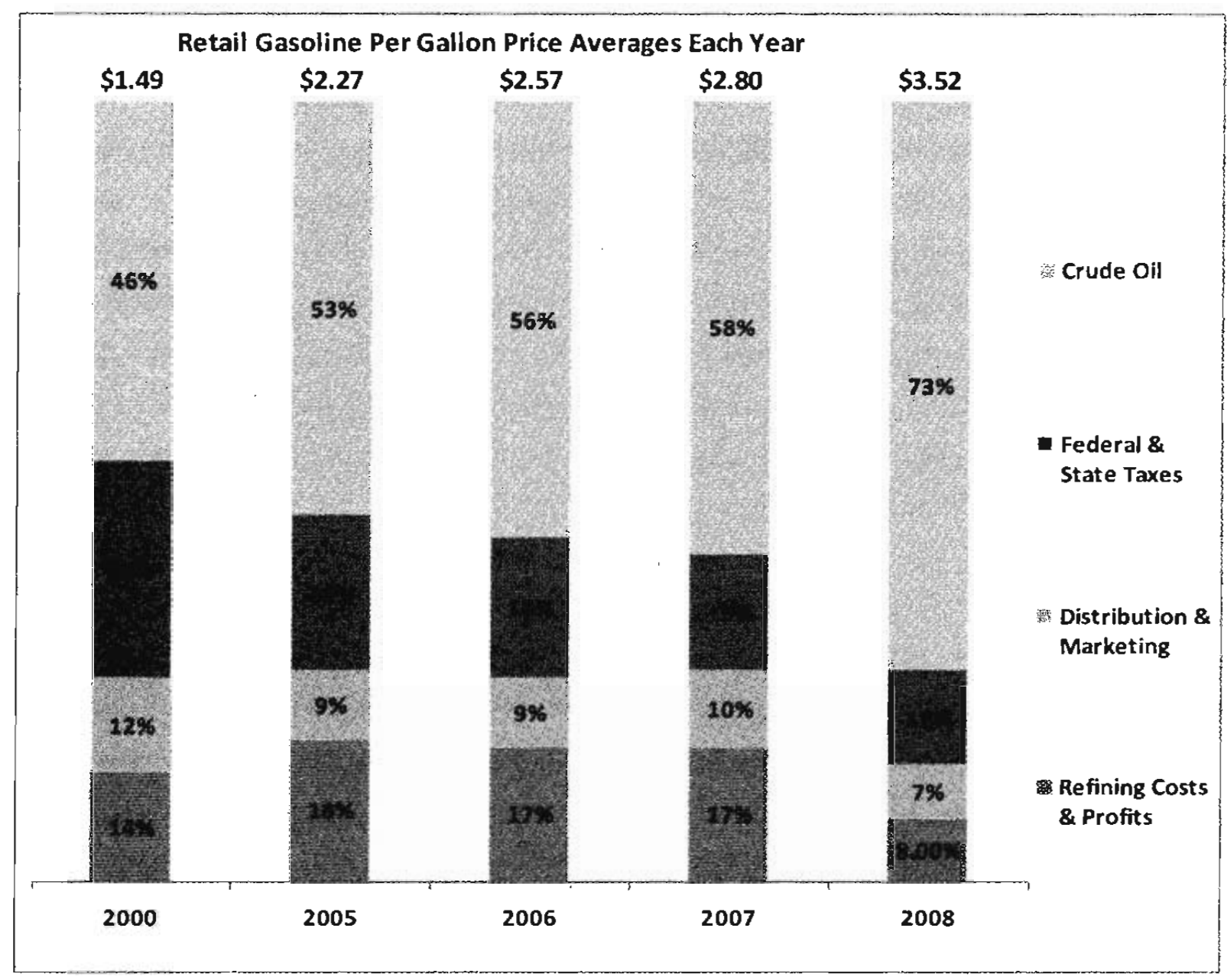

Source: Energy Information Administration, Washington, DC Information for 2008 is from January 2008 to August 2008

Several recent studies have considered asymmetries. These include both asymmetries in retail gasoline price dynamics and asymmetries in the responses of macroeconomic variables to increases in oil prices, as opposed to decreases in oil prices. Important examples are Borenstein, Cameron, and Gilbert (1997) who showed that gasoline prices increase more rapidly when crude oil prices increase 
than they decline when crude oil prices decrease. They also contended that unbranded gasoline outlets change their prices in a similar fashion to branded gasoline stations (those with company-specific additives and with the right to use the refiner's name at resale). The price differential is rarely more than one cent over unbranded gasoline prices. Asymmetry is prevalent for both spot and futures prices. Changes in oil prices today may be a good determinate for predicting future changes in gas prices, but inventories may also be a contributor. A model was formulated in the paper to estimate the responses of gasoline prices to oil price changes, and to look at the asymmetry between the two. The model is expressed as $\mathrm{R}=\Phi_{0}+\Phi_{1} \mathrm{C}+\varepsilon$, where $\mathrm{R}$ is the retail gasoline price per gallon, $\mathrm{C}$ is the price of crude oil per gallon, and $\varepsilon$ is a normal and i.i.d. error term. While their model is similar to the model that we are using, they looked at the responsiveness of the change in crude oil price to the change in gas price to note the asymmetry between the two and not as a formal way to model the price change itself from the futures price of crude oil.

The Deltas (2005) paper used monthly 1988-2002 data for the 48 contiguous states (except Nevada) to test the hypothesis of asymmetric responses of retail gasoline prices to changes in wholesale prices. Price increases are passed on to the retail customer more quickly than price decreases. Asymmetry is also dependent on the average retail-wholesale margin of a state. Larger margin states experience greater asymmetries than smaller margin states.

A different type of asymmetric behavior was examined by Brown, Yucel, and Thompson (2003). They found that economic expansion over the business cycle from a decrease in oil prices is not as large as the decrease in economic activity when the oil prices rise. Monetary policy seems to be less accommodative when oil prices increase due to inflation pressures and when oil importing countries experience slower growth due to decreased demand when prices increase.

The Davis and Hamilton (2004) paper looked at the causes of price stickiness and determined which has the greatest impact on gas prices. The cost due to administrative expenses associated with changing a posted price called "menu costs" was the first cause they looked at. The next explanation deals with the costs due to lack of perfect, timely information that gives rise to a firm committing to capacity constraints before they know what supply shocks occur. Third, competition discourages price changes due to the possibility of losing market share. They conclude that the most important factors entering the decision to change or not change prices are menu costs and expected reactions of customers and competitors.

The Chouinard and Perloff (2002) study estimated a model to determine what significance taxes, pollution regulations, mergers, market power, and market condi- 
tions have on the changes in gas prices. Their findings show that over the last several decades the main contributor to changes in gas prices has been increases in the prices of crude oil. Also, they found that a tax decrease on gas is the only way to significantly decrease the price of gas in the short run.

Borenstein and Shephard (1996) researched a form of tacit collusion between retail gasoline markets. Collusion may be possible in the gasoline markets even though there are a large number of sellers, because these stations sell a product that is differentiated by brand, service, and location. Retail margin is defined as the retail price minus the wholesale price of gasoline. They estimated that approximately twothirds of the eventual pass-through of crude oil price changes occurred in the first two weeks following the shock. The results showed lower margins when demand is expected to decline next period than when it is expected to increase, and margins are higher when wholesale prices are expected to decline next period than when they are expected to increase. Also, there is more incentive to raise prices in a timely fashion than lower them.

Lewis (2004) suggests that there is less incentive to reduce retail prices than increase them. Consumers engage in fewer searches for low prices when prices are falling. Therefore, retailers experience less competition. He also suggests that consumers may not gain anything from a more intensive search when prices are rising since there is an opportunity cost of time used in the search process.

During the summer of 2007 , we continued to make an effort to gain institutional knowledge of retail gasoline pricing decisions by asking local owners and managers what caused them to change retail gasoline prices. A local owner of five retail outlets selling unbranded product was willing to talk with us, as was the pricing manager of a branded product line with numerous retail outlets locally and in the region.

Both indicated that retail prices are far more "sticky" than wholesale prices, and neither uses futures markets to hedge against possible increases in the cost of gasoline. Both buy in the spot market daily at a price set by refiners at 6:00 p.m. for tomorrow's delivery. Both pay a great deal of attention to the prices that their competitors charge, so a form of tacit collusion may exist. Profit margins are very small with an attempt to net 6 cents per gallon over substantial periods of time before the cost of credit card use, which is both common and costly, in that it reduces the attempt to net 6 cents by 50 percent.

An interesting aspect of the unbranded retailer's management is an attempt to generate positive profits by controlling costs from a refinery. This is done by shopping the numerous wholesale outlets in the state of Texas on a daily basis. Sometimes 
the price differences are as high as 18 cents per gallon, so it may be less expensive to buy in San Antonio (400 miles away) and pay the freight costs, and still net 3 cents over local outlets. The branded retailer has less flexibility because he agrees to buy only from the refinery that adds his brand's additives. In exchange, he is guaranteed a daily supply of gasoline while the unbranded outlet is sometimes "out."

While our discussions with the two enhanced our understanding of the retail gasoline market, we left with a sense of loss regarding who sets prices and what prices are based on. We did corroborate the sticky price models that exist in the literature and that individual outlets feel subject to the pressures of a highly competitive market. We are left with attempting to predict gas prices and the change in gas prices from the futures prices of crude oil.

\section{Model and Data}

In determining the behavior between these two variables it is necessary to observe their relationships and possible synchronization over time. The levels of retail gasoline prices and the futures prices of crude oil can be seen in Figure 2 for the 1990-2008 sample period. Using this Figure, it is clearly apparent that there is a significant positive relationship between the two variables. At first glance, we find that it is a bit less clear on whether the futures prices of crude oil move before or after the retail gasoline prices. This can be tested properly using a Granger causality test which we complete in the next section.

The data we used were obtained from the Energy Information Administration (EIA) website from August 20, 1990 to August 25, 2008. Our data include weekly crude oil future contracts priced in dollars per barrel at Cushing, OK, weekly average prices of retail gasoline in the United States, and the percentage that each component contributes to the price of a gallon of gasoline. These components were discussed above.

Based on our assumption that, at the margin, shocks to existing retail gasoline prices come from changes in futures prices of crude oil, and futures prices predict spot retail unleaded gasoline prices; the model that we specify here is as follows:

$$
\mathrm{G}_{\mathrm{t}}=\alpha_{1}+\beta_{0} \mathrm{O}_{\mathrm{t}}+\beta_{\mathrm{i}} \mathrm{O}_{\mathrm{t}-\mathrm{i}}+\varepsilon_{\mathrm{t}}(\mathrm{i}=1-3)
$$

$\mathrm{G}_{t}$ is the national retail weekly average of regular unleaded gasoline prices in time period t. $\mathrm{O}_{\mathrm{t}}$ is the weekly average futures price of crude oil in week t one-month before delivery. $\varepsilon_{\mathrm{t}}$ is the i.i.d. error term. 
Figure 2

\section{Weekly Average Retail Gasoline and Crude Oil Futures Prices}

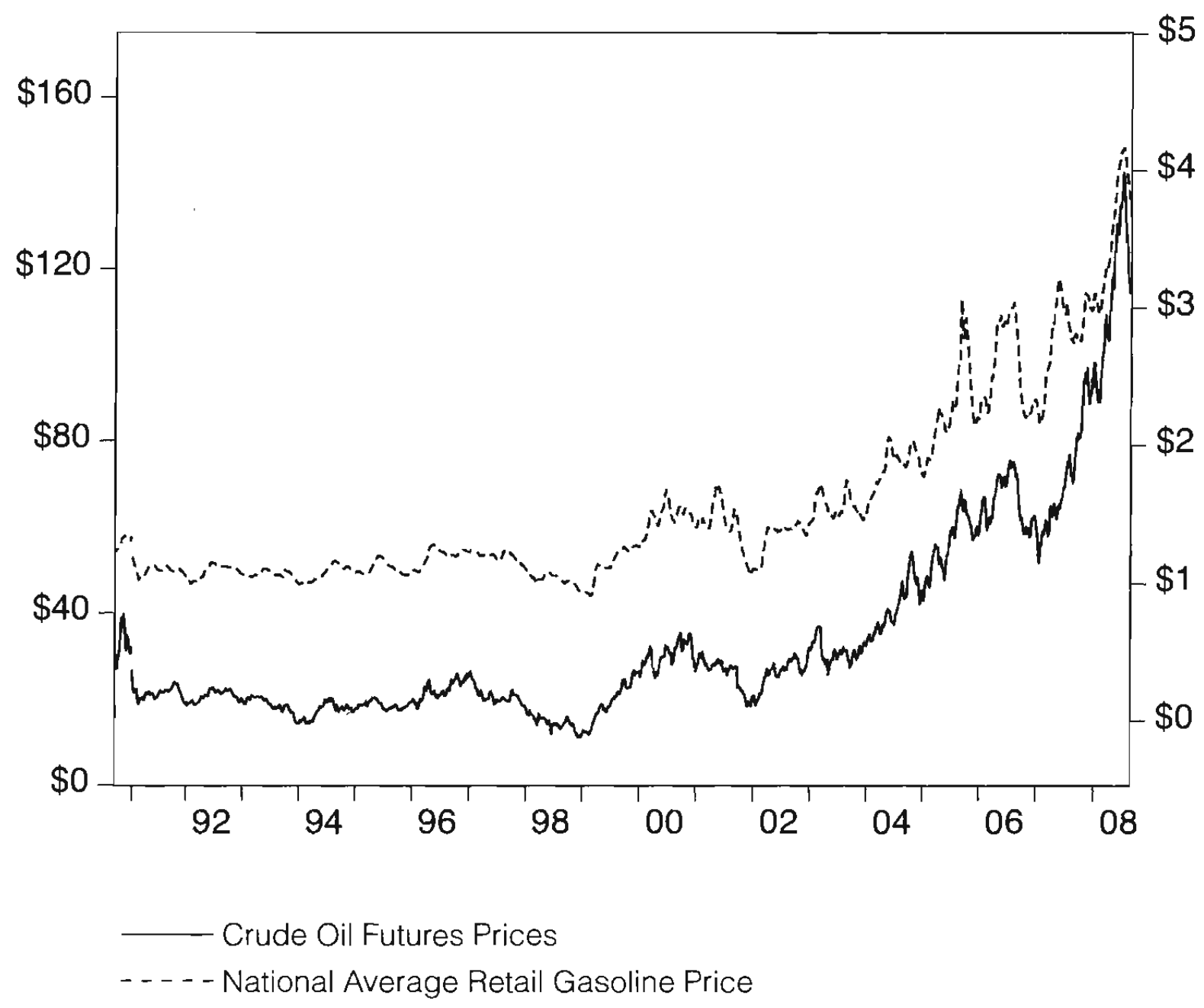

Note: The values used in this figure are the levels of the weekly average prices of a gallon of retail gasoline and the weekly average of futures prices of a barrel of crude oil from August 20, 1990 to August 25, 2008.

Values on the left $Y$ axis are the levels of the average weekly crude oil futures priced in dollars.

Values on the right $Y$ axis are retail the levels of the average weekly retail gasoline priced in dollars.

We then investigated which form of these variables would provide us with meaningful results. To determine this, we look at the stationarity issue of our variables. If the variables are nonstationary, we will be left with meaningless results because there is a trend in the data based on time. The values that we identified that were stationary were the first differences of the logged values of the two variables, because both the levels and logged values appeared to be nonstationary. After transforming these variables into first differences of the logs and examining the character- 
istic roots in relationship with the unit circle, we were able to have a tested assumption that the first differences of the logged values are stationary. These transformed variables are used in our evaluations of the model in this paper.

\section{Estimation Results}

As mentioned in the previous section, we want to test to be confident of causality from oil to gas prices. We did this using a Granger causality test. Since one of our key assumptions is that futures prices of crude oil cause spot retail unleaded gasoline prices to rise, then this test is essential for us to move forward. While it is still possible that oil prices may cause gas prices to rise or fall, this test would increase the level of confidence that we have in our evaluation. After completing the Granger causality test, we can reject the hypothesis that the futures prices of crude oil fail to Granger cause gas prices. The test provides a reasonable basis to use the futures prices of crude oil to forecast spot retail unleaded gasoline prices over the sample period that we have chosen.

Table 1 presents the results of two OLS regressions. These results consist of a linear regression model that regresses the current weekly average national retail prices of gas on the current weekly average futures prices of crude oil and crude prices two or three weeks prior to the current week. In analyzing the results in Table 1 , we determine that the Schwarz Bayesian criterion (SBC) is the best measure to evaluate the goodness-of-fit of our model. While the $\mathrm{R}^{2}$ measure gives a value that provides a better fit with a fourth lagged variable of the futures price of crude oil, the SBC begins to increase when this variable is added to the model. The increase in the SBC shows that the extra variable increases the penalty and does not increase the model's performance. Therefore, we find that three lagged periods of the futures prices of crude oil gives us the best fit, and provides a statistically significant model to evaluate the accuracy of predicting the future spot retail unleaded gasoline prices. This model allows for parsimony and a sufficient closeness of fit between the actual and fitted first values. These results and the residuals are found in Figure 3.

Therefore, it appears that using the current and three previous periods of the futures prices of crude oil is the best model to provide econometric testing of our ability to predict spot retail unleaded gasoline prices. Since all of our variables are expressed as the percentage change from one period to the next, the estimated coefficients are the elasticity measures with respect to each independent variable. From these coefficient values, we can state that a $10 \%$ increase in the current weeks average of the futures prices of crude oil will have a positive $2 \%$ effect on the current 
weeks average of spot retail unleaded gasoline prices. A $10 \%$ increase in each additional past weekly averages of futures prices of crude oil, including the previous three weeks, will have a $1 \%, 0.7 \%$, and $0.7 \%$ increase in gas prices respectively. Summing up, the current weeks average change in oil prices will have the biggest effects on gas prices, but the other weeks included in the model will be significant as well.

Table 1

Estimates of Gas Price Expectations

Using the First Difference of the Logged Values

$$
G_{t}=\alpha_{1}+\beta_{0} O_{t}+\beta_{1} O_{t-1}+\beta_{2} O_{t-2}+\varepsilon_{t}
$$

\begin{tabular}{cccc}
\hline Variable & Coefficient & Std. Error & \\
\hline Const & 0.000579 & 0.000482 & \\
$\mathrm{O}_{t}$ & 0.210254 & 0.012398 & $\star \star \star \star$ \\
$\mathrm{O}_{t-1}$ & 0.101589 & 0.012405 & $\star \star \star \star$ \\
$\mathrm{O}_{t-2}$ & 0.082453 & 0.012289 & $\star \star \star \star$ \\
\hline
\end{tabular}

$R^{2}=0.324757$

$\mathrm{SBC}=-5.578013$

$$
G_{t}=\alpha_{1}+\beta_{0} O_{t}+\beta_{1} O_{t-1}+\beta_{2} O_{t-2}+\beta_{3} O_{t-3}+\varepsilon_{t}
$$

\begin{tabular}{cccc}
\hline Variable & Coefficient & Std. Error & \\
\hline Const & 0.000475 & 0.000473 & \\
$\mathrm{O}_{1}$ & 0.204354 & 0.012244 & $\star \star \star$ \\
$\mathrm{O}_{t-1}$ & 0.108747 & 0.012302 & $\star \star \star \star$ \\
$\mathrm{O}_{t-2}$ & 0.072072 & 0.012228 & $\star \star \star$ \\
$\mathrm{O}_{1-3}$ & 0.077643 & 0.012085 & $\star \star \star \star$ \\
\hline
\end{tabular}

$R^{2}=0.353728$

$\mathrm{SBC}=-5.613580$

Note: The data set that was used is the first difference of the logged values of the weekly average prices of a gallon of retail gasoline $\left(G_{r}\right)$ and the weekly average of futures prices of a barrel of crude oil $\left(\mathrm{O}_{\mathrm{t}}\right)$ from August 20, 1990 to August 25, 2008. $\varepsilon_{\mathrm{t}}$ is a normal and i.i.d. error term.

${ }^{\star \star \star}$ statistically significant. 
Figure 3

Fitted and Actual Values from

$G_{t}=\alpha_{1}+\beta_{0} O_{t}+\beta_{1} O_{t-1}+\beta_{2} O_{t-2}+\beta_{3} O_{t-3}+\varepsilon_{t}$

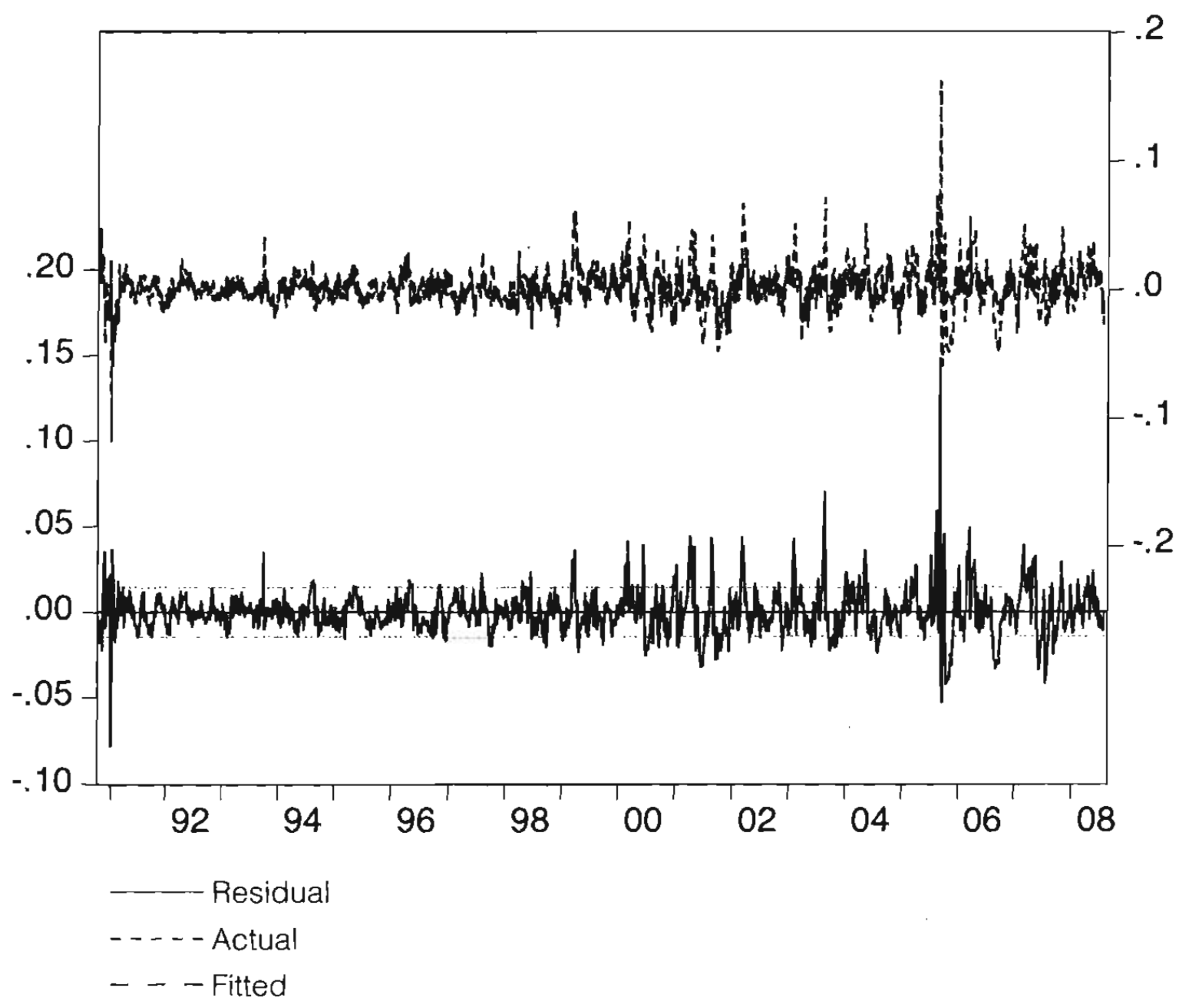

Note: The values used in this figure to attain the fitted and actual values from the model are the first difference of the logged values of the weekly average prices of a gallon of retail gasoline (DLOG(RG)) and the weekly average of futures prices of a barrel of crude oil (DLOG(CO)) from August 20, 1990 to August 25, 2008.

Values on $Y$ axis are percentages.

Using the data from August 20, 1990 to August 25, 2008, a dynamic forecast was studied. This forecast is shown in Figure 4. The findings during this time period for the actual and forecasted weekly average of gas prices seem to show a consistent measurement for these changes. Figure 4 also shows that there seems to be a break between the actual retail gasoline prices and the forecasted gas prices that should have prevailed if our model is accurate. The model does a very good job of replicat- 
ing the swings in gas prices inside the confidence interval from 1990 to 2000 . From 2000 to 2008 , the forecast of gas prices from the model has deviated more noticeably from the actual gas prices relative to the former time period. There are many possible reasons for this break in accuracy of our model between the two time periods. While the explanation of the reasoning behind the break in these time periods is not in the scope of this paper, it is necessary to break up our entire sample period into these two time periods and see how well our model does.

After separating these two time periods, we used the $1990-2000$ period to forecast what our model would have estimated on a weekly basis for gasoline prices and related it to the actual gasoline prices in Figure 5. Our model provides pleasing results using this sample period to forecast what the gasoline prices will be relative to the actual gasoline prices until 1999. This is the essential reason why we have decided to split the entire sample period up in 2000. During this period, from 1999 to 2000 , there may have been a shift in the way in which gasoline prices and oil prices were tied together.

In further analyzing this information, we took the 2000-2008 period and used our model to forecast what the gasoline prices should be. After attaining this information, we compared it with the actual gasoline prices during this period. This comparison can be found in Figure 6. Using this sample period to forecast predictions of gas prices has been improved upon relative to forecasting over the entire sample period. Beginning in 2000 until the middle of 2005 , our model does a good job of fitting closely with the actual gasoline prices. After the summer of 2005, over the next three years our model seems to have trouble accurately predicting gasoline prices. One key to this time period has been random shocks from the anticipation of hurricanes and actual hurricanes, such as Hurricane Katrina, that have caused numerous shutdowns of refineries in the Gulf of Mexico. These sorts of random shocks to the system are just that, random, and our model is not capable of taking into account these effects that are not caused by a sudden increase in the prices of oil. While this may be the case, the actual gasoline prices do move in the direction of where our model shows that the price should be in a short period after the refineries have been put back online.

Finally, we look at the period from April 28, 2008 to September 22, 2008. During this period of time, oil prices and gas prices have fluctuated rather dramatically. The futures prices of crude oil reached a high around $\$ 145$ a barrel in July, and shortly after, decreased to $\$ 91$ a barrel. This fluctuation in oil prices has had significant effects on the price of gasoline as well. The national average of retail gas prices during this time hit a high of above $\$ 4$ a gallon and then fell far below $\$ 4$ as the price 
of crude oil decreased. Figure 7 tells the story that once again our model was a good indicator of where the gas prices should be and eventually will be as actual prices rose then fell with a lag relative to crude oil futures. Near the end of this sample period the actual gas prices average has diverted from the model's predictions. This is clearly due to another random shock to the system with Hurricane Ike in the Gulf of Mexico. Many refineries were shutdown along the Texas and Louisiana coast causing supply disruptions in the gasoline industry. While the forecast and actual gasoline prices diverted from each other, we have seen that actual gasoline prices have converged to what the model has predicted as refineries got back online and supply disruptions were eased.

Figure 4

Dynamic Forecast and Actual Retail Gasoline Prices

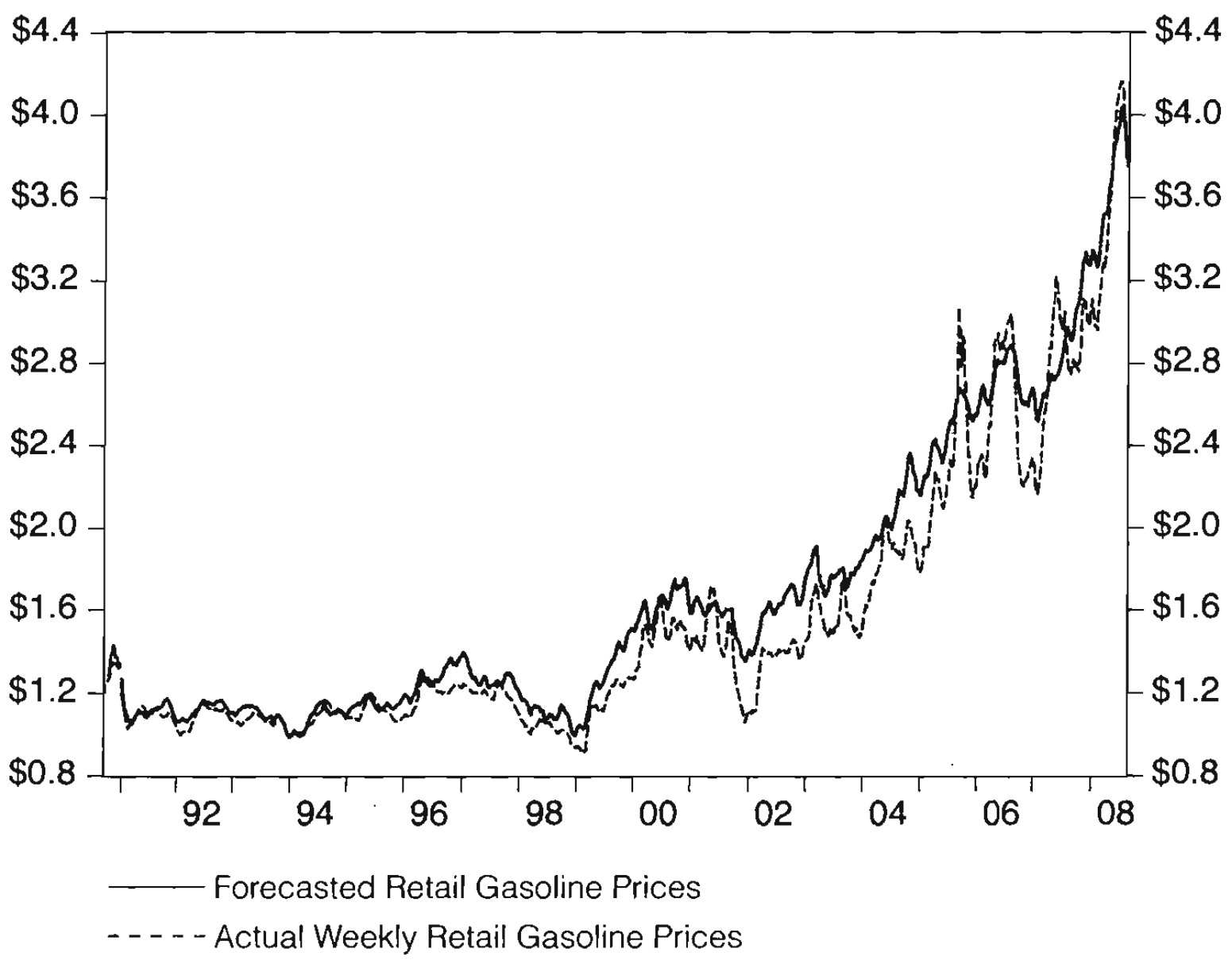

Note: The values used in this figure to attain the forecast for the period 1990-2008 from the model are the first difference of the logged values of the weekly average prices of a gallon of retail gasoline $(G)$ and the weekly average of futures prices of a barrel of crude oil (O) from August 20, 1990 to August 25, 2008.

Values on $Y$ axis are percentages. 
Figure 5

Dynamic Forecast and Actual Retail Gasoline Prices from 1990-2000

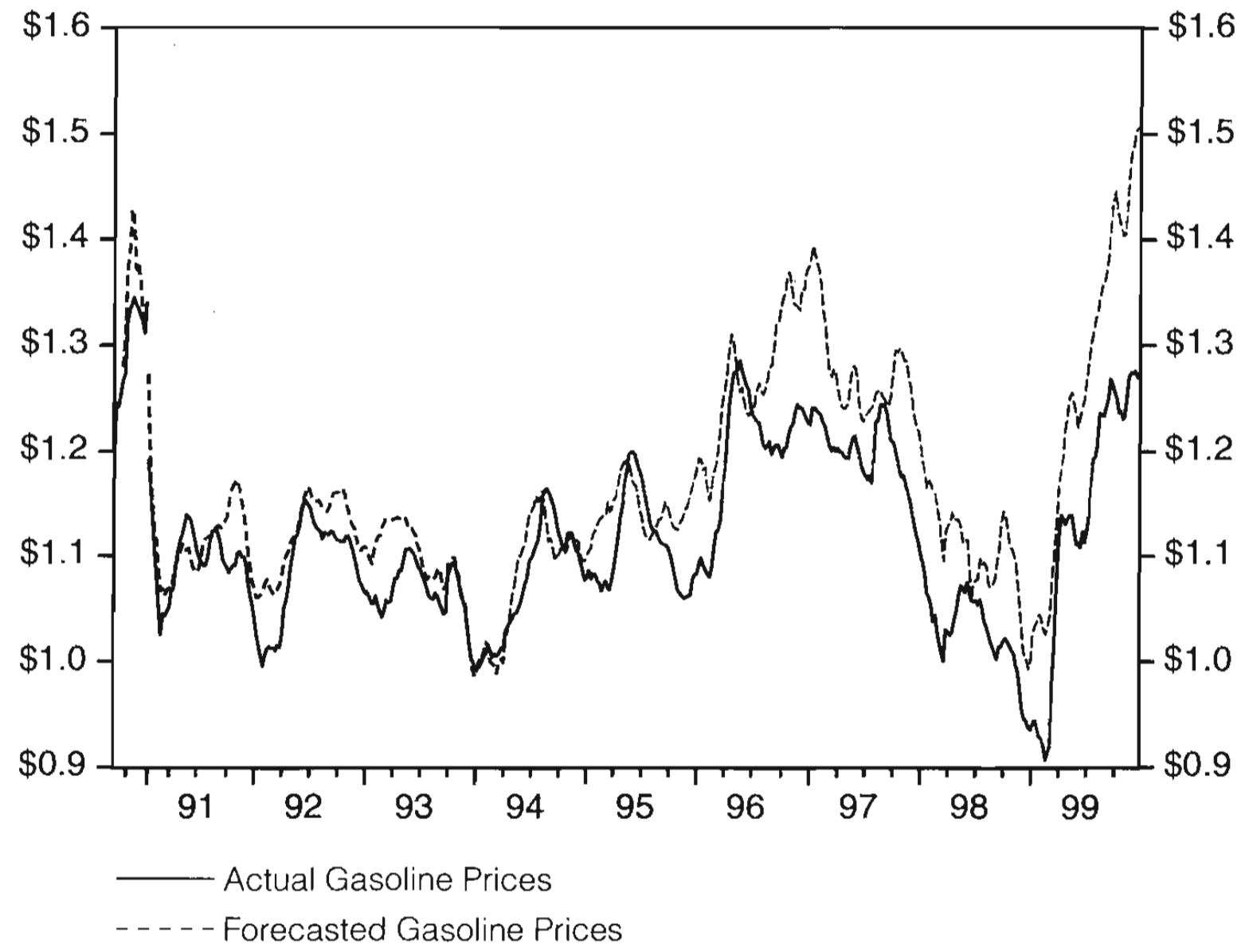

Note: The values used in this figure to attain the forecast for the period 1990-2000 from the model are the first difference of the logged values of the weekly average prices of a gallon of retail gasoline $(G)$ and the weekly average of futures prices of a barrel of crude oil (O) from August 20, 1990 to December 31, 1999.

Values on the $Y$ axis are the levels of the average weekly retail gasoline prices in dollars.

As crude oil prices fell 75 percent from their July 2008 highs to their February 2009 lows, consumers often questioned why retail gasoline prices were not falling as fast and as much as crude oil prices. What happened to actual gasoline prices versus what our model predicted during this period can be seen in Figure 8. During September and October of 2008, consumers' questions were on target. Using current and lagged crude oil prices, our model forecasted lower gasoline prices than existed. However, during the last two months of 2008 , the opposite happened. Then from the end of the year until mid-February 2009, retail gas prices reverted to what our model forecasted. That is, they increased until they were within three cents of our forecast. What consumers did not seem to understand was that early in 2009 , retail gas prices 
increased as crude oil prices continued to fall because earlier gasoline prices had decreased more than the decrease in crude oil prices would have predicted.

\section{Figure 6}

\section{Dynamic Forecast and Actual Retail Gasoline Prices from 2000-2008}

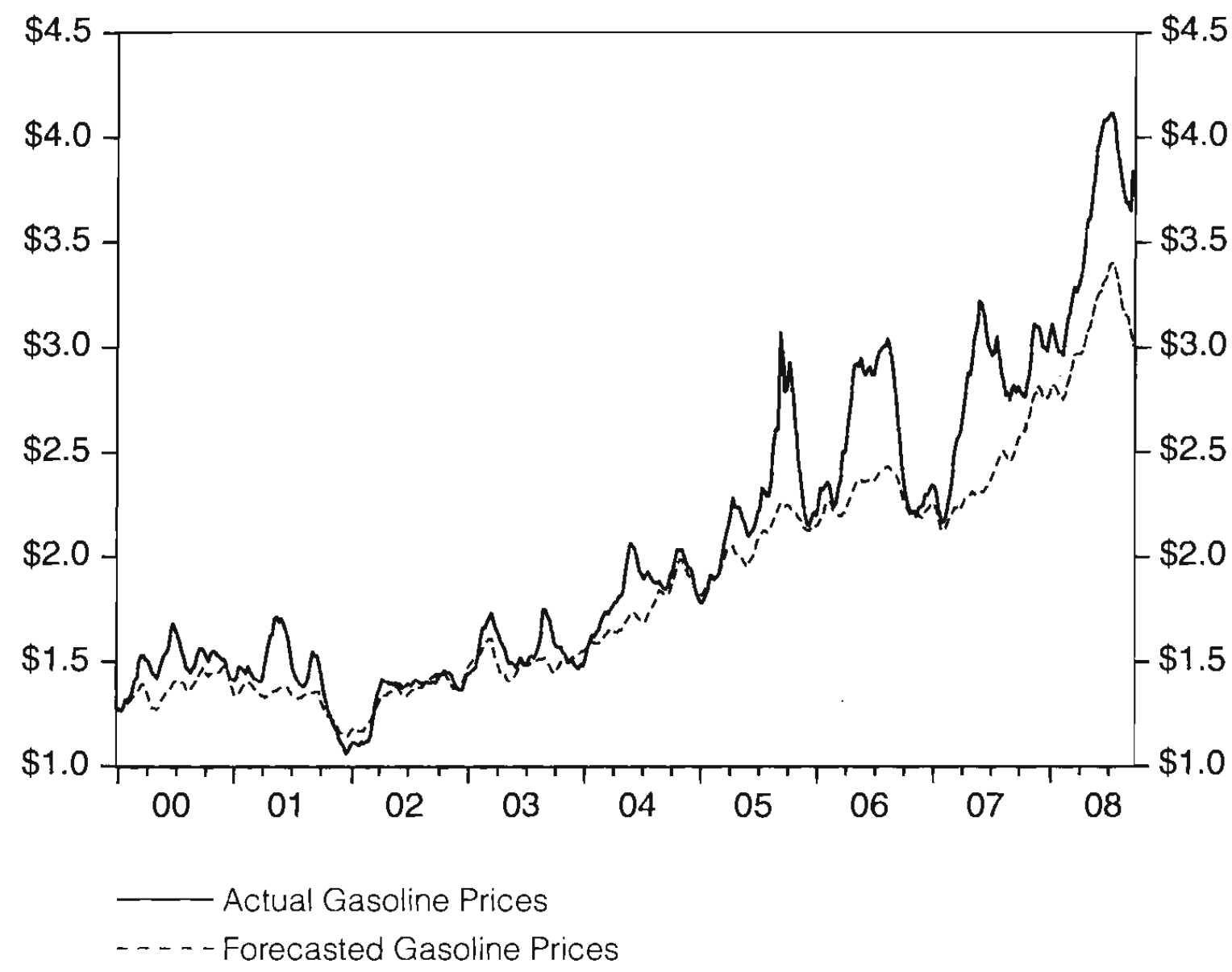

Note: The values used in this figure to attain the forecast for the period 2000-2008 from the model are the first difference of the logged values of the weekly average prices of a gallon of retail gasoline $(G)$ and the weekly average of futures prices of a barrel of crude oil (O) from January 1, 2000 to September 22, 2008.

Values on the $Y$ axis are the levels of the average weekly retail gasoline prices in dollars. 
Figure 7

\section{Dynamic Forecast and Actual Retail Gasoline Prices}

from April 28, 2008 to September 22, 2008

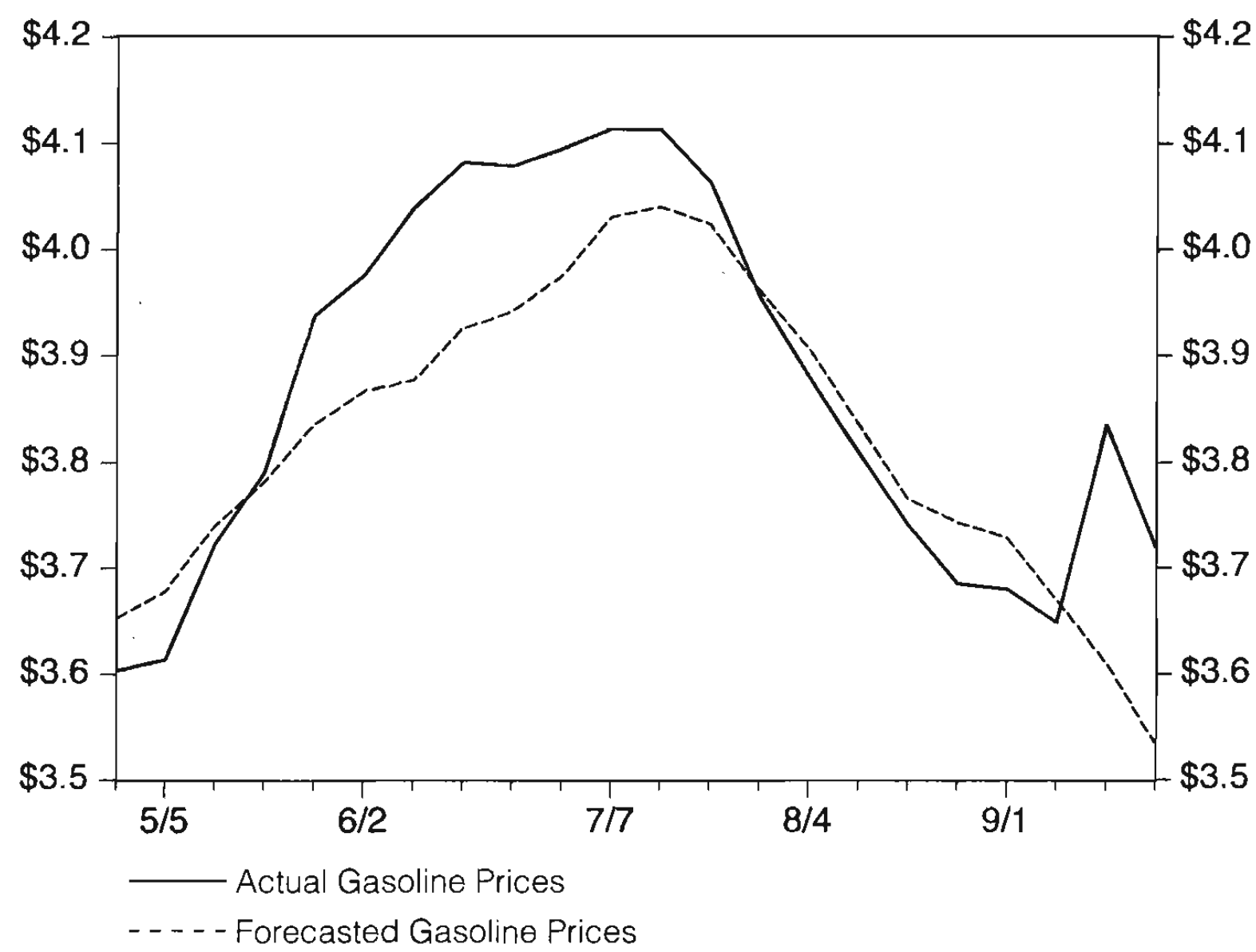

Note: The values used in this figure to attain the forecast for the period April 28, 2009 to September 22, 2009 from the model are the first difference of the logged values of the weekly average prices of a gallon of retail gasoline $(G)$ and the weekly average of futures prices of a barrel of crude oil (O) from April 28, 2008 to September 22, 2008.

Values on the $Y$ axis are the levels of the average weekly retail gasoline prices in dollars. 


\section{Figure 8}

\section{Dynamic Forecast and Actual Retail Gasoline Prices \\ from September 9, 2008 to February 9, 2009}

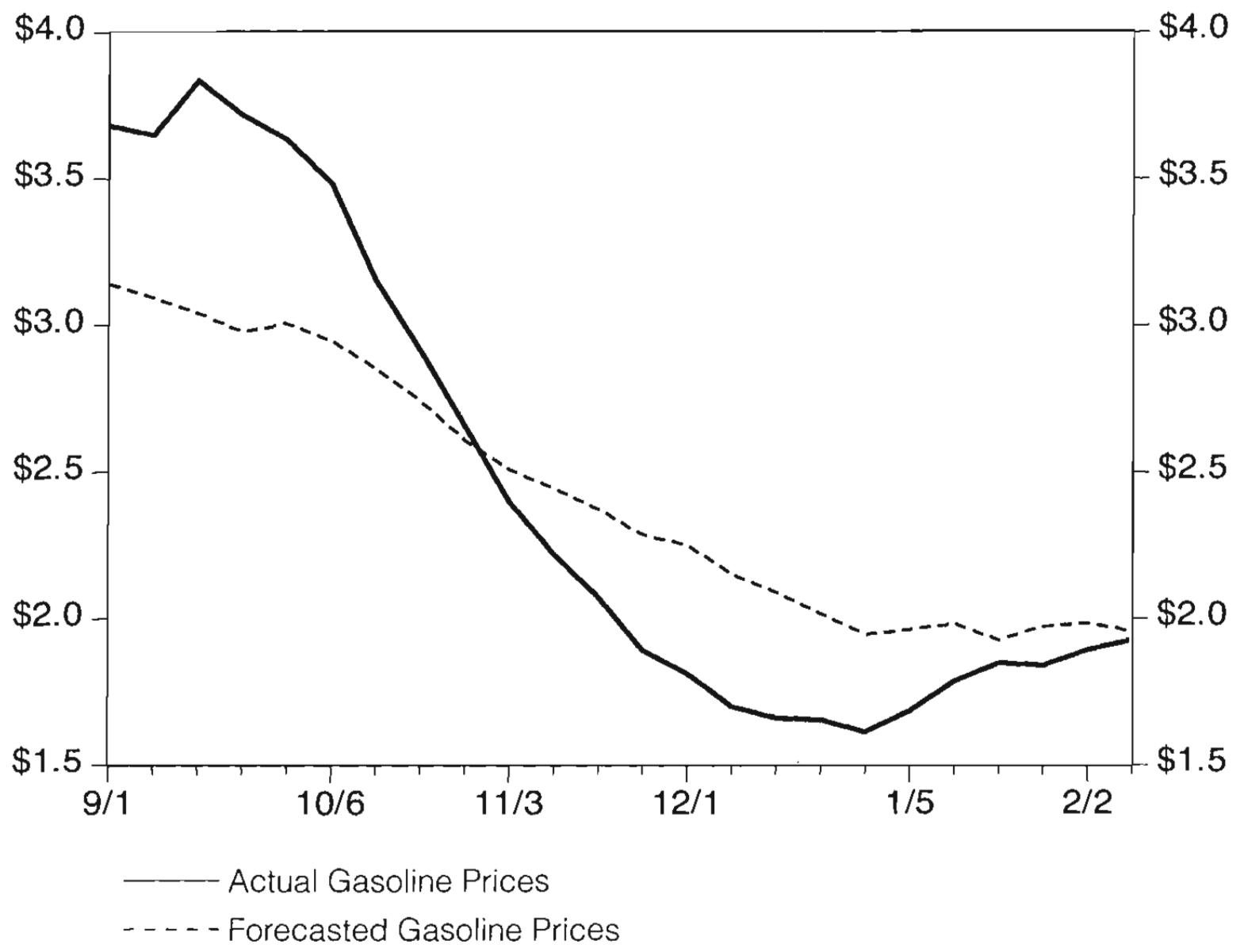

Note: The values used in this figure to attain the forecast for the period September 1 , 2008 to February 15, 2009 from the model are the first difference of the logged values of the weekly average prices of a gallon of retail gasoline $(G)$ and the weekly average of futures prices of a barrel of crude oil $(O)$ from September 1, 2008 to February 15, 2009. Values on the $Y$ axis are the levels of the average weekly retail gasoline prices in dollars.

\section{Conclusion}

Our paper began with a question, "Can crude oil futures prices predict spot retail unleaded gasoline prices?" Our econometric evidence supports an affirmative response to this question. Both the percentage change in weekly unleaded gasoline prices and the rate of change in those prices can be predicted with current and lagged futures prices of crude oil. Since we have a linear model, we are able to evaluate the elasticity of an increase in the futures prices of crude oil relative to the retail gasoline prices; therefore, we can conclude from our model that a $10 \%$ increase in the current 
weeks average futures prices of crude oil will cause an increase in the current weeks average retail gasoline prices of about $2 \%$. In addition, the lags appear to be very brief with lengths of three weeks being sufficient to achieve a very good fit.

These results were even better than we expected, given our discussions with owners of unbranded and branded gasoline outlets in our area. They indicated that they do not use futures markets in determining their pricing behavior of gas. It may be that these outlets focus more on transportation and refining costs while larger outlets pay more attention to futures prices. If this is the case, this would allow our assumption to hold true as the larger outlets make up a bigger portion of the gasoline market; therefore, the futures prices are prevalent in the decision making process.

We are aware that while our model predicts well on average over our sample period, predicting future gasoline prices may be difficult at times due to exogenous shocks that are not included in our model. Some of the possible exogenous shocks have been discussed in this paper. Other shocks that may have an impact would include gasoline inventories, fiscal policy changes, and an assortment of other possibilities. These exogenous shocks are random in nature and will not be able to be properly modeled in the short run. Even though this may be the case, in the medium to long run gas prices seem to move more in line with our model.

Future research will include providing an error correction model that will allow for the speed in which gas prices return to their estimated trend. This would help in reducing the deviation between actual and estimated gasoline prices. Since there has been a significant amount of volatility recently with crude oil futures and gasoline prices, it will be necessary to continue to compare the model versus the actual gasoline prices. If we are able to accurately model the direction and magnitude of gasoline prices on a consistent basis, the implications will lead to having a better idea of how random shocks affect energy prices, how the predictions affect business cycles, how this would affect monetary policy, and a host of other possible research topics arising from predicting the average weekly retail unleaded gasoline prices.

It is our goal to allow for a better understanding of gasoline prices and how the price changes occur to allow for other solutions to come about. Thus far, our conclusion is that the weekly average futures prices of crude oil can predict spot retail unleaded gasoline prices. 


\section{References}

American Petroleum Institute. (2008). Gasoline taxes. Retrieved October 8, 2008, from www.api.org/statistics/fueltaxes/upload/October_2008_gasoline_and_diesel_summary_pages.pdf.

Borenstein, S. (1991). Selling costs and switching costs: Explaining retail gasoline margins. RAND Journal of Economics, 22, 354-369.

Borenstein, S., Cameron, A. C., \& Gilbert, R. (1997). Do gasoline prices respond asymmetrically to crude oil price changes? The Quarterly Journal of Economics, 112(1), 305-339.

Borenstein, S., \& Shephard, A. (1996). Dynamic pricing in retail gasoline markets. RAND Journal of Economics, 27, 429-451.

Brown, S., Yucel, M. K., \& Thompson, J. (2003). Business cycles: The role of energy prices. The Federal Reserve Bank of Dallas. Research Department. Working Paper 0304.

Chouinard, H., \& Perloff, J. M. (2002). Gasoline price differences: Taxes, pollution regulations, mergers, market power, and market conditions. Retrieved September 1, 2007, from are.berkeley.edu/ perloff/PDF/gasoline.pdf

Davis, M. C., \& Hamilton, J.D. (2004). Why are prices sticky? The dynamics of wholesale gasoline prices. Journal of Money, Credit, and Banking, 36(1), 17-37.

Deltas, G. (2007). Asymmetries in retail gasoline price dynamics and local market power. Retrieved September 1, 2007, from www.physics.fst.usp.ac.fj/fileadmin/ files/schools/ssed/economics/working_papers/2005/wp2005_11.pdf.

Energy Information Administration. (2008). Gas stocks (U.S. weekly finished gasoline ending stocks (thousand barrels)). Retrieved September 28, 2008, from tonto.eia.doe.gov/dnav/pet/pet_sum_sndw_dcus_nus_w.htm.

Energy Information Administration. (2008). Weekly crude oil prices (Cushing, OK crude oil future contract I (dollars per barrel)). Retrieved September 28, 2008, from tonto.eia.doe.gov/dnav/pet/pet_pri_fut_s1_d.htm.

Energy Information Administration. (2008). Weekly retail gasoline prices (U.S. regular all formulations retail gasoline prices (cents per gallon)). Retrieved September 28, 2008, from tonto.eia.doe.gov/dnav/pet/pet_pri_gnd_dcus_nus_w. htm.

Energy Information Administration. (2008). A primer on gasoline prices. Retrieved September 28, 2008, from tonto.eia.doe.gov/oog/info/gdu/gasdiesel.asp.

Haubrich, J. G., Higgins, P., \& Miller, J. (2004). Oil prices: Backward to the future? The Federal Reserve Bank of Cleveland. Economic Commentary. 
Herce, M., Parsons, J. E., \& Ready, R. C. (2006). Using futures prices to filter shortterm volatility and recover a latent, long-term price series for oil. Center for Energy and Environmental Policy Research. Working Paper 06-005.

Jones, D. W., Leiby, P.N., \& Paik, I. K. (2004). Oil price shocks and the macroeconomy: What has been learned since 1996. The Energy Journal, 25(2).

Lewis, M. (2004). Asymmetric price adjustment and consumer search: An examination of the retail gasoline market. Competition Policy Center. Working Paper No. CPC04-47.

Nosal, E. (2001). How well does the federal funds futures rate predict the future Federal Funds Rate? The Federal Reserve Bank of Cleveland. Economic Commentary.

Williams, J. L. (2005). Oil prices and analysis. Retrieved February 6, 2007, from www.wtrg.com/prices.htm.

\section{Biographical Sketch of Authors}

Vance Ginn is a third year Ph.D. student in economics at Texas Tech University. His interests include macroeconomics and public policy, especially energy policy.

Ronald D. Gilbert, Ph.D., is an economics professor at Texas Tech University where he teaches and does research in monetary theory and policy. He is especially interested in conventional and unconventional central bank monetary polices as they relate to the global financial crisis. He has recently published in Applied Economics and Journal of Economics. 
